\title{
POLITIK HUKUM PUTUSAN PENGADILAN AGAMA YANG MENYIMPANGI PASAL 105 (a) K.H.I TENTANG HAK ASUH ANAK YANG BELUM MUMAYYIZ DALAM KASUS PERCERAIAN MARSHANDA VS BEN KASYAFANI
}

\author{
Tan, Henny Tanuwidjaja \\ Dosen Fakultas Hukum Universitas Narotama Surabaya \\ Korespondensi: t.tanuwidjaja@yahoo.com
}

\begin{abstract}
Abstrak
Hukum merupakan entitas sangat kompleks. Hukum mencakup bermacam realitas sosial dan terdiri dari banyak aspek serta dimensi. Perkembangan hukum berakar dari proses interaksi antar bebagai aspek dari masyarakat. Hukum ditetapkan oleh masyarakat dan bentuknya ditentukan oleh sifat khusus suatu masyarakat. Melalui artikel ini penulis membahas perspektif politik hukum Putusan Pengadilan Agama Jakarta dalam kasus perceraian antara Marshanda dan Ben Kasyafani yang pada dasarnya tidak sesuai dengan Pasal 105 (a) Kompilasi Hukum Islam (KHI). Putusan tersebut hendaknya dipahami sebagai putusan berdasarkan kebijakan, ketimbang berdasarkan aturan hukum.
\end{abstract}

Kata-kata Kunci: Politik Hukum; Putusan Pengadilan Agama; Perceraian.

\begin{abstract}
Law is a very complex entity. It covers diverse social reality and consists of many aspects and dimensions. The development of law is rooted in the process of interactions among various aspects of the society. It is established by the society, and its shape is determined by the particular nature of the society. In this paper the author examines the legal political perspective of Jakarta Religious Court decision in divorce case between Marshanda and Ben Kasyafani that basically diverted from the provisions of Article 105 (a) of the Compilation of Islamic Law (KHI). The decision is understood as based on policy, rather than on legal rules.
\end{abstract}

Key Words: Legal Policy; Religious Court Decision; Divorce. 


\section{PENDAHULUAN}

Politik hukum merupakan disiplin ilmu paling muda dibandingkan dengan disiplin-disiplin hukum lain seperti sejarah hukum, sosiologi hukum, antropologi hukum, filsafat hukum dan lain-lain. ${ }^{1}$ Namun demikian itu bukan berarti bahwa politik hukum tidak memiliki posisi strategis sebagai sebuah ilmu yang dari sisi aksiologis mampu untuk menguak misteri hukum sama baiknya dengan disiplin-disiplin hukum yang telah ada sebelumnya. ${ }^{2}$ Bila kita berbicara tentang akar sejarah timbulnya politik hukum, mau tidak mau kita berbicara tentang latar belakang, kapan, di mana, dan siapa yang menggagas disiplin ilmu ini untuk pertama kalinya. $^{3}$

Satjipto Rahardjo berusaha untuk menjelaskan struktur keilmuan politik hukum yang meliputi aspek tujuan, metode dan ruang lingkupnya. Penjelasannya tersebut pada tahap awal dapat membantu para mahasiswa fakultas hukum untuk memahami keberadaan disiplin ilmu ini. Meski demikian, penjelasan tersebut masih belum cukup untuk memberikan pemahaman yang tuntas terhadap anatomi keilmuan politik hukum. ${ }^{4}$

Ruang lingkup disiplin ilmu politik hukum meliputi aspek lembaga kenegaraan pembuat politik hukum, letak politik hukum dan faktor (internal dan eksternal) yang mempengaruhi pembentukan politik hukum suatu negara, seperti di negara kita siapa di antara badan-badan negara yang berwenang dalam proses penentuan politik hukum, apakah kekuasaan legislatif, eksekutif atau yudisial? ${ }^{5}$ Dan dalam peraturan perundang-undangan mana saja politik hukum suatu negara itu dapat ditemukan? Tiga permasalahan itu baru sebatas membahas proses pembentukan politik hukum, belum berbicara pada tataran aplikasi berupa implementasi produk hukum yang merupakan konsekuensi politis dari suatu "politik hukum". ${ }^{6}$

Menurut Imam Syaukani dan A. Ahsin Thohari, politik hukum adalah suatu ilmu sekaligus seni yang pada akhirnya mempunyai tujuan praktis untuk memungkinkan peraturan hukum positif dirumuskan secara lebih baik dan untuk memberi pedoman, tidak hanya kepada pembuat undang-undang, tetapi juga kepada pengadilan yang menetapkan undang-undang dan juga kepada para penyelenggara atau pelaksana putusan pengadilan. ${ }^{7}$ Senada dengan pembelajaran teori-teori politik hukum, penulis merasa bahwa Putusan Pengadilan Agama Jakarta Pusat atas kasus perceraian Marsyanda dan Ben

Surat Keputusan Menteri Pendidikan dan Kebudayaan Republik Indonesia Nomor 002/U/2006, Politik Hukum menjadi salah satu kuliah wajib secara nasional, program Pasca Sarjana. Imam Syaukani dan A. Ahsin Thohari, Dasar-Dasar Politik Hukum (Rajawali Press 2012) 3.

Satjipto Rahardjo, Ilmu Hukum (Citra Aditya Bakti 1991) 351-353.

Satjipto Rahardjo, Beberapa Pemikiran Tentang Ancangan Antar Disiplin Dalam Pembinaan Hukum Nasional (Sinar Baru 1985) 2.

Soedjono Dirdjosisworo, Pengantar Ilmu Hukum (Rajawali Press 1999) 48

Imam Syaukani dan A.Ahsin Thohari, Op.Cit. 50.

M.Hamdan, Politik Hukum Pidana (Raja Grafindo Persada 1997) 13. 
Kasyafani tersebut dari perspektif politik hukum ternyata telah bertentangan dengan ketentuan Pasal 105 (a) Kompilasi Hukum Islam Indonesia (KHI) tentang hak asuh anak yang belum mumayyiz (belum berumur 12 tahun) yang seharusnya merupakan hak asuh ibunya (Marshanda), namun Majelis Hakim telah memutuskan bahwa hak asuh anak tersebut diserahkan kepada ayah kandungnya (Ben Kasyafani). Hal ini menurut penulis merupakan Enactment Policy ${ }^{8}$ yang sejalan dengan pendapat dari Hikmahanto Juwana yang membagi politik hukum menjadi dua:

1) Politik Hukum Yang Ditetapkan: Kebijakan Dasar (Basic Policy), yaitu alasan mendasar dari diadakannya suatu undang-undang. Contoh: Pasal 105 (a) KHI yang berbunyi, "Dalam hal terjadi perceraian, pemeliharaan anak yang belum mumayyiz atau belum berumur 12 tahun adalah hak ibunya." Pengaturan undang-undang tersebut dimaksudkan adalah: Kebijakan Dasar pembentukan KHI Pasal 105 (a) tersebut adalah memberikan perlindungan hukum bagi anak yang belum mumayyiz dan jaminan terpenuhinya pengasuhan dan pemeliharaan anak yang belum berumur 12 tahun dalam pengawasan dan pemeliharaan langsung oleh ibunya;

2) Kebijakan Pemberlakuan Politik Hukum (Enactment Policy), yaitu tujuan atau alasan yang muncul di balik pemberlakuan suatu Undang-
Undang. Contoh, Keputusan Majelis Hakim Jakarta Pusat terhadap hak asuh anak yang belum mumayyis ternyata telah memutuskan menyerahkan hak asuh dan pengawasan anak Marshanda dan Ben Kasyafani yang belum mumayyiz kepada Ben Kasyafani. Dan ternyata keputusan majelis Hakim tersebut telah menyimpangi ketentuan Pasal 105 (a) KHI yang menetapkan bahwa dalam hal terjadi perceraian, pemeliharaan anak yang belum mumayyiz atau belum berumur 12 tahun adalah hak ibunya. Dalam hal ini menurut penulis, majelis hakim menerapkan Kebijakan Pemberlakuan Politik Hukum (Enactment Policy) menyimpang dari ketentuan Pasal 105 (a) KHI.

\section{Rumusan Masalah}

1. Apakah putusan majelis hakim pengadilan agama Jakarta Pusat terhadap kasus perceraian Marsyanda dan Ben Kasyafani benar demi hukum?

2. Apa pertimbangan Majelis Hakim Pengadilan Agama untuk menerapkan keputusan yang tidak sesuai dengan isi Pasal 105 (a) KHI sehingga Hak Asuh Pengawasan anak di bawah umur 12 tahun diserahkan kepada Ayahnya, Ben Kasyafani?

Krisnadi Nasution, Sejarah dan Politik Hukum (Magister Universitas Tujuh Belas Agustus Surabaya 2014) 19. 


\section{PEMBAHASAN}

Dalam banyak kejadian sejarah kenegaraan politik hukum merupakan upaya menjadikan hukum sebagai sarana pencapaian tujuan bernegara, juga sebagai Instrumen Politik "Law is as a tool of politic". Sedangkan manfaat memahami materi sejarah politik hukum adalah: Sebagai bekal upaya menyingkap tabir apa sesungguhnya yang melatarbelakangi sebuah peraturan hukum atau Undang-Undang itu dihasilkan (ius constituendum-ius constitutum); sehingga hal ini bisa membantu kita untuk memahami esensi hukum itu yang sesungguhnya jauh lebih kompleks dari sekedar persoalan rumusan norma dalam pasal-pasal.

Selain diakui secara akademik, pada tataran empiris Politik Hukum telah digunakan oleh Moh. Mahfud M.D dan Benny K.Harman sebagai pendekatan dalam memahami relasi antara hukum dan politik. Baik Mahfud maupun Harman menurut penulis dapat dikatakan sebagai dua contoh terbaik dalam kasus ini, dari karya ilmiah keduanya terbaca bahwa baik Mahfud maupun Benny K. Harman mencoba menghadirkan sebuah pendekatan yang berbeda dalam memahami sebuah fenomena hukum. Dalam hal ini berbeda dengan pendekatan klasik yang melihat hukum dari sisi yuridis normatif saja. Sedangkan Mahfud dan Harman melihat hukum dari sisi yuridis sosio-politis, yaitu menghadirkan sistem politik sebagai variebel yang mempengaruhi rumusan dan pelaksanaan hukum. Berdasarkan hasil penelitiannya, Mahfud berkesimpulan bahwa suatu proses dan konfigurasi politik tertentu akan sangat signifikan pengaruhnya terhadap suatu produk hukum yang kemudian dilahirkannya. Dalam negara yang konfigurasi politiknya demokratis, produk hukumnya berkarakter ortodoks atau konservatif atau elitis ${ }^{10}$.

Han Kelsen dalam bukunya "General Theory of Law and State" menuliskan sebagai berikut:

The contitution in the formal sense is a certain solemn document, a set of legal norms that may be changed only under the observation of special prescriptions, the purpose of which it is to render the change of these norms more difficult. The constitution in material sense consists of those rules which regulate the creation of the general legal norms, in particular the creation of statutes ${ }^{11}$

Artinya: Konstitusi dalam arti formal adalah dokumen serius tertentu, seperangkat norma hukum yang dapat berubah hanya di bawah pengawasan khusus, yang tujuannya adalah untuk membuat perubahan norma ini agak lebih sulit. Konstitusi dalam arti materi terdiri dari aturan-aturan yang mengatur pembentukan norma hukum umum, khususnya penciptaan undangundang. Selanjutnya politik hukum. Menurut Mahfud MD, adalah legal policy

Moh. Mahfud MD, Politik Hukum Di Indonesia, (LP3ES 1998) 363.

Hans Kelsen, General Theory of Law and State (The Lawbook Exchange, Ltd. 1973) 124. Petikan dari Imam Syaukani dan A. Ahsin Thohari, Op.Cit., 88. 
atau garis kebijakan resmi tentang hukum yang akan diberlakukan baik dengan pembuatan hukum baru maupun dengan penggantian hukum lama, dalam rangka mencapai tujuan hukum. ${ }^{12}$ Definisi yang pernah dikemukakan oleh beberapa pakar lain antara lain, Satjipto Raharjo mendefinisikan politik hukum sebagai aktivitas memilih dan cara yang hendak dipakai untuk mencapai suatu tujuan sosial dengan hukum tertentu di dalam masyarakat yang cakupannya meliputi jawaban atas pertanyaan mendasar, yaitu :

1) Tujuan apa yang hendak dicapai dengan sistem yang ada;

2) Cara-cara apa dan yang bagaimana yang dirasa paling baik untuk dipakai dalam mencapai tujuan tersebut;

3) Kapan waktunya dan melalui cara bagaimana hukum itu perlu diubah;

4) Dapatkah suatu pola yang baku dan mapan dirumuskan dalam memutuskan proses pemilihan tujuan serta cara-cara untuk mencapai tujuan tersebut dengan baik. ${ }^{13}$

Sedangkan menurut Roscoe Pound, "law as a tool of social engineering" yaitu Hukum determinan atas politik: Hukum harus mampu mengendalikan dan merekayasa perkembangan masyarakat, termasuk kehidupan politiknya. Karena dengan itu fungsi hukum untuk menjamin dan melindungi kepentingan masyarakatnya akan menjadi lebih relevan.

Sebelum penulis membahas tentang topik tulisan yang berjudul: Perspektif Politik Hukum Terhadap Penerapan pasal 105 (a) Kompilasi Hukum Islam (K.H.I) atas hak anak asuh yang belum mumayyis dari Kasus Perceraian "Marshanda VS Ben Kasyafani" terlebih dahulu penulis akan meninjau seperangkat Undang-Undang tentang pengaturan Hak Asuh Anak setelah perceraian menurut UU No. 1 Tahun 1974, berkaitan dengan UU No. 23 Tahun 2002 dan UU No. 4 Tahun 1979 serta UU No. 3 Tahun 1997. Dan Undang-Undang Hukum Perdata (B.W) khususnya Hukum Keluarga dan Perikatan, sebagai bahan pendukung.

Apabila mengacu pada hukum keluarga, bahwa sebelum bicara masalah hak asuh anak dan masalah perceraian, maka terlebih dahulu harus dipahami mengenai proses yang mendahuluinya, yaitu perkawinan. Tanpa perkawinan, tidak mungkin ada perceraian.

Perkawinan adalah upaya menyatukan dua pribadi yang berbeda satu sama lain. Dalam kenyataannya tidak semua perkawinan dapat berlangsung dengan langgeng dan tentunya tidak ada seorangpun yang ingin perkawinannya berakhir dengan jalan perceraian. Dengan putusnya suatu perkawinan berdasarkan putusan

12 Mahfud MD, Politik Hukum Di Indonesia (Rajawali Pers 2009) 1.

13 Satjipto Raharjo, Op.Cit., 2. 
pengadilan yang telah berkekuatan hukum tetap (inkracht van gewijsde), maka akan ada akibat-akibat hukum yang mengikutinya, salah satunya adalah mengenai hak asuh atas anakanak yang lahir dari perkawinan tersebut.

Jika direnungkan secara filosofi, maka sebelum melangkah untuk mengambil suatu putusan "bercerai" maka seyogyanya logika harus ada pada upaya menentukan prinsip-prinsip moral dan sosial secara rasional. Prinsip-prisip itu kemudian menjadi patokan untuk menilai pilihan bagi pihak yang berkepentingan untuk bertindak mengambil suatu keputusan ${ }^{14}$. Seperti dikatakan oleh Sokrates: "Hidup yang tidak dikaji tak pantas untuk dihidupi”, suatu tindakan politik atau moral, misalnya pemberontakan sipil, harus dibimbing oleh rasio bukan oleh suatu gagasan spontan ataupun keinginan menggantungkan diri sendiri karena emosional sesaat.

\section{Akibat Hukum Dari Putusnya Perkawinan Karena Perceraian}

Berdasarkan ketentuan Pasal 41 UU No. 1 Tahun 1974 disebutkan bahwa akibat dari putusnya suatu perkawinan karena perceraian adalah:

a. Baik ibu atau bapak tetap berkewajiban memelihara dan mendidik anak-anaknya, sematamata berdasarkan kepentingan anak, bilamana ada perselisihan mengenai penguasaan anak-anak, Pengadilan memberi keputusannya.

b. Bapak yang bertanggung jawab atas semua biaya pemeliharaan dan pendidikan yang diperlukan anak itu, bilamana bapak dalam kenyataannya tidak dapat memberi kewajiban tersebut pengadilan dapat menentukan bahwa Ibu ikut memikul biaya tersebut.

c. Pengadilan dapat mewajibkan kepada bekas suami untuk memberikan biaya penghidupan dan/atau menentukan sesuatu kewajiban bagi bekas isteri.

Berdasarkan Pasal 41 UU No. 1 Tahun 1974 tersebut di atas, maka jelas bahwa meskipun suatu perkawinan sudah putus karena perceraian, tidaklah mengakibatkan hubungan antara orang tua (suami dan isteri yang telah bercerai) dan anak-anak yang lahir dari perkawinan tersebut menjadi putus. Sebab dengan tegas diatur bahwa suami dan istri yang telah bercerai tetap mempunyai kewajiban sebagai orang tua yaitu untuk memelihara dan mendidik anak-anaknya, termasuk dalam hal pembiayaan yang timbul dari pemeliharaan dan pendidikan dari anak tersebut.

Ketentuan di atas juga menegaskan bahwa negara melalui UU No. 1 Tahun 1974 tersebut telah memberikan perlindungan hukum bagi kepentingan anak-anak yang perkawinan orang

14 Bernard Arief Sidharda, Refleksi tentang Struktur Ilmu Hukum. Sebuah penelitian tentang fondasi Kefilsafatan dan sifat keilmuan, Ilmu Hukum sebagai landasan pengem bangan Ilmu Hukum Nasional Indonesia (Penerbit Mandar Maju 1999) 116. 
tuanya putus karena perceraian. Permohonan Untuk Mendapatkan Hak Asuh. Perlu dicermati bahwa ketentuan Pasal 41 huruf (a) UU No. 1 Tahun 1974 pada bagian terakhir menyatakan bahwa "bilamana ada perselisihan mengenai penguasaan anak-anak, pengadilan memberi keputusannya."

Berlandaskan ketentuan tersebut, maka dalam suatu gugatan perceraian, selain dapat dimohonkan agar perkawinan diputus sah oleh pengadilan, maka salah satu pihak juga berhak memohon kepada hakim agar diberikan hak asuh atas anak-anak (khususnya yang masih di bawah umur) yang lahir dari perkawinan tersebut.

Dalam UU No. 1 Tahun 1974 sendiri memang tidak terdapat definisi mengenai hak asuh tersebut, namun jika kita melihat Pasal 1 angka 11, UU No. 23 Tahun 2002, terdapat istilah "Kuasa Asuh" yaitu kekuasaan orang tua untuk mengasuh, mendidik, memelihara, membina, melindungi, dan menumbuh kembangkan anak sesuai dengan agama yang dianutnya dan kemampuan, bakat, serta minatnya.

Sedangkan Ketentuan Kompilasi Hukum Islam (KHI) nampaknya tidak dapat berlaku secara universal karena hanya akan mengikat bagi mereka yang memeluk agama Islam (yang perkaranya diperiksa dan diputus di Pengadilan Agama). Sedangkan untuk orang-orang yang bukan beragama Islam yang perkaranya diperiksa dan diputus di Pengadilan Negeri), tidak ada pedoman yang secara tegas mengatur batasan pemberian hak asuh bagi pihak yang menginginkannya, maka hakim dalam menjatuhkan putusannya akan mempertimbangkan antara lain:
Pertama : Fakta-fakta yang terungkap dipersidangan;

Kedua : Bukti-bukti yang diajukan oleh para pihak;

Ketiga : Argumentasi yang dapat meyakinkan hakim mengenai kesanggupan dari pihak pemohon atas Hak Asuh Anak pasangan tersebut dalam mengurus dan melak sanakan kepentingan dan pemeliharaan anak tersebut baik secara materi, pendidikan, jasmani dan rohani.

Selain itu juga dalam Pasal 1 angka 10, UU No. 23 Tahun 2002 terdapat pula istilah "Anak Asuh" yaitu "Anak yang diasuh" oleh seseorang atau lembaga, untuk diberikan bimbingan, pemeliharaan, perawatan, pendidikan, dan kesehatan, karena orang tuanya atau salah satu orang tuanya tidak mampu menjamin tumbuh-kembang anak secara wajar. Seluk Beluk Pemberian Hak Asuh Anak sesuai uraian di atas tentunya akan timbul suatu pertanyaan, siapakah diantara bapak atau ibu yang paling berhak untuk memperoleh Hak Asuh atas anak tersebut.

Satu-satunya aturan yang dengan jelas dan tegas memberikan pedoman bagi hakim dalam memutus pemberian hak asuh atas anak tersebut terdapat 
dalam Pasal 105 KHI yang menyatakan dalam hal terjadi perceraian :

a) pemeliharaan anak yang belum mumayyiz atau belum berumur 12 tahun adalah hak ibunya.

b) pemeliharaan anak yang sudah mumayyiz diserahkan kepada anak untuk memilih di antara ayah atau ibunya sebagai pemegang hak pemeliharaan.

c) biaya pemeliharaan ditanggung oleh ayahnya.

Sidang kasus perceraian Ben dan Marshanda digelar di Pengadilan Agama Jakarta Pusat, dan putusan perceraian dibacakan pada hari Selasa tanggal 25 Nopember 2014. Ben Kasyafani dan Marshanda menikah pada tanggal 2 April 2011 di Bidakara Assembly Hall, Jakarta. Dari pernikahan tersebut lahir seorang putri yang diberi nama Sienna Ameerah Kasyafani. Pada tanggal 23 April 2014, Marsyanda menggugat cerai sang suami, Ben Kasyafani dengan alasan perbedaan agama, karena menurut Marshanda, ia tidak menghendaki Ben menjadi anggota Lembaga Dakwah Islam Indonesia (LDII). Ia melayangkan gugatan cerai kepada Ben Kasyafani ke Pengadilan Agama Jakarta Pusat pada tanggal 23 April 2014 kemudian menjalani proses persidangan dengan fakta dan saksi. Menurut pengacara Ben, Denny Kailimang, gugatan tersebut sudah dimediasi selama satu bulan, tapi tidak berhasil.
Dalam proses persidangan perceraian, Marshanda mencantumkan masalah hak asuh anak bahwa ia mengaku tidak mau adanya perebutan hak asuh anak. Seperti komitmen yang diutarakan, Marshanda ingin Sienna dibesarkan oleh dirinya dan Ben Kasyafani. Namun demikian akhirnya Majelis Hakim pada tanggal 25 November 2015 berhasil menjatuhkan dua putusan yang isinya sebagai berikut:

$\begin{aligned} \text { Pertama : } & \begin{array}{l}\text { Menerima gugatan } \\ \text { penggugat } \\ \text { perceraian; }\end{array} \\ \text { Kedua }: & \begin{array}{l}\text { Hak Asuh Pengawasan } \\ \text { terhadap anak dari }\end{array} \\ & \text { Marshanda dan Ben } \\ & \text { diterima majelis hakim } \\ & \text { untuk Ben Kasyafani. }\end{aligned}$

Majelis Hakim Pengadilan Agama Jakarta Pusat, menurut penulis telah mengambil suatu keputusan yang bijaksana semata-mata demi kepentingan pemeliharaan anak Ben dan Marshanda, meskipun hasilnya telah menyimpangi ketentuan Pasal 105 (a) KHI, hal ini sesuai teori hukum yang dikemukakan oleh pakar hukum Hikmahanto Juwana, yaitu "Kebijakan Pemberlakuan Politik Hukum (Enactment Policy)" adalah suatu kebijakan pemberlakuan yaitu tujuan atau alasan yang muncul di balik pemberlakuan suatu Undang-Undang.

Hakim Pengadilan Agama dalam keputusannya telah menyimpang dari 
ketentuan Pasal 105 (a) KHI yang menentukan bahwa hak asuh anak yang belum mumayyiz (yang belum genap berumur 12 tahun) adalah hak ibunya, dengan mengambil suatu kebijaksanaan keputusan sendiri yang bertentangan dengan Pasal 105 (a) KHI tersebut dengan menyerahkan hak asuh dan pengawasan anak yang belum mumayyiz tersebut kepada Ben Kasyafani, Ayah Sienna Ameerah Kasyafani, bukan kepada ibunya. Hal ini merupakan satu lagi yurisprudensi tentang penyerahan hak asuh pengawasan anak yang belum mumayyiz kepada ayahnya.

Dari uraian tersebut dapat penulis simpulkan bahwa dasar pertimbangan Majelis Hakim dalam pengambilan keputusan perceraian tersebut adalah :

1. Semata-mata dengan pertimbangan untuk lebih memberikan perlindungan yang aman dan pasti terhadap hak asuh, pemeliharaan pengawasan terhadap si Anak. Karena dari pertimbangan majelis hakim bahwa "Marshanda diduga mengidap ganguan kejiwaan bipolar disorder tipe II".

2. Majelis hakim juga berpendapat bahwa tujuan dari rumah tangga sudah tidak sesuai lagi dengan Undang-Undang Perkawinan yang sakinah, jadi lebih banyak mudaratnya dari pada manfaatnya, sehingga hal ini merupakan salah satu pertimbangan untuk memutuskan perceraian antara Marshanda dan Ben Kasyafani.
3. Majelis hakim juga memberikan catatan bahwa tidak ada pemutusan hubungan silaturahmi antara ibu dan anak, ibu tetap ibu, dan bapak tetap bapak dari anak, intinya walaupun perwalian jatuh ke pihak Ben, majelis menyarankan bahwa ada hak ibu kandung, karena menyangkut anak di bawah umur.

\section{PENUTUP}

\section{Kesimpulan}

1. Putusan majelis hakim Pengadilan Jakarta Pusat atas Kasus perceraian Marshanda dan Ben Kasyafani jika ditinjau dari sudut pemberlakukan kebijaksanaan politik hukum menurut penulis dapat dibenarkan, karena keputusan kasus perceraian yang menyangkut hak asuh anak yang diserahkan kepada ayahnya, semata-mata adalah demi kepentingan dan kesejahteraan si anak.

2. Pertimbangan hakim atas putusan perceraian yang bertentangan dengan isi ketentuan Pasal 105 (a) KHI adalah sebagai berikut:

a. Semata-mata demi kepentingan pengawasan dan kesejahteraan bagi anak.

b. Marshanda diduga mengidap gangguan kejiwaan bipolar disorder tipe II sehingga menurut pertimbangan hakim kurang menjamin hak asuh pengawasan dan kesejahteraan terhadap si anak. 
c. Bahwa perkawinan Marsyanda dan Ben Kasyafani tidak sesuai lagi dengan tujuan UU No. 1 Tahun 1974 yang harus sakinah, namun lebih banyak mudaratnya (tidak menguntungkan/gagal) daripada manfaatnya.

\section{Saran}

Sesuai kodratnya, anak dilahirkan adalah pemberian Tuhan Y.M.E melalui kedua orang tuanya, sama sekali bukan atas kehendak anak ingin dilahirkan, jika toh si anak telah dilahirkan, bayi itu adalah suci dan tanpa dosa. Apabila suatu hari terjadi peristiwa hukum yaitu perceraian dari orang tuanya yang tidak terelakan, maka siapapun salah satu dari orang tuanya dan khususnya yang oleh pengadilan ditetapkan sebagai penerima hak asuh pengawasan terhadap anak hasil perkawinannya, maka salah satu orang tua atau bahkan keduanya harus tetap berkewajiban dan bertanggung-jawab sepenuhnya terhadap pemeliharaan, pengawasan dan pembiayaan hidup serta biaya pendidikan si anak tersebut, sebagai perwujudan perlindungan dan kasih sayang terhadap si anak yang tak berdosa tersebut sampai ia dewasa dan mandiri.

\section{DAFTAR BACAAN}

\section{Buku}

Sidharda, Bernard Arief, Refleksi tentang Struktur Ilmu Hukum. Sebuah penelitian tentang fondasi
Kefilsafatan dan sifat keilmuan. Ilmu Hukum sebagai landasan Pengembangan Ilmu Hukum Nasional Indonesia (Mandar Maju 1999).

Hamdan, M., Politik Hukum Pidana (Raja Grafindo Persada 1997).

Kelsen, Hans, General Theory of Law and State (The Law book Exchange, Ltd. 1973).

Syaukani, Imam \& A.Ahsin Thohari, Dasar-Dasar Politik Hukum (Rajawali Press 2012).

MD., Mahfud, Politik Hukum Di Indonesia (Rajawali Pers 2009).

Nasution, Krisnadi, Sejarah dan Politik Hukum (Magister Universitas Tujuh Belas Agustus Surabaya 2014).

Rahardjo, Satjipto, Beberapa Pemikiran Tentang Ancangan Antar Disiplin Dalam Pembinaan Hukum Nasional (Sinar Baru 1985).

Rahardjo, Satjipto, Ilmu Hukum (Citra Aditya Bakti 1991).

Siswoyo, Soedjono Dirdjo, Pengantar Ilmu Politik (Rajawali Press 1999). 